NBER WORKING PAPER SERIES

\title{
RECIPROCATED UNILATERALISM IN TRADE REFORMS WITH MAJORITY VOTING
}

\author{
Pravin Krishna \\ Devashish Mitra \\ Working Paper 10826 \\ http://www.nber.org/papers/w10826
NATIONAL BUREAU OF ECONOMIC RESEARCH 1050 Massachusetts Avenue
Cambridge, MA 02138
October 2004

For helpful discussions we are grateful to Kyle Bagwell, Jagdish Bhagwati, Arvind Panagariya, Dani Rodrik and seminar audiences at Boston College, Brandeis University, University of British Columbia, Brown University, University of California at Irvine, Columbia University, University of Connecticut, Dartmouth College, Florida International University, New York University, University of Notre Dame, Syracuse University, Yale University and the annual meetings of the American Economic Association. The views expressed herein are those of the author(s) and not necessarily those of the National Bureau of Economic Research.

(C2004 by Pravin Krishna and Devashish Mitra. All rights reserved. Short sections of text, not to exceed two paragraphs, may be quoted without explicit permission provided that full credit, including $\odot$ notice, is given to the source. 
Reciprocated Unilateralism in Trade Reforms with Majority Voting

Pravin Krishna and Devashish Mitra

NBER Working Paper No. 10826

October 2004

JEL No. F1

\section{ABSTRACT}

This paper shows how unilateral liberalization in one country can increase the voting support for reciprocal reduction in trade barriers in a partner country. When trade policies are determined simultaneously in the two countries, we show the possibility of multiple political equilibria - countries may both be protectionist or trade freely with each other. Starting with trade protection in both countries, a unilateral reform in one country is thus shown to bring about a free trade equilibrium (a self-enforcing state) that is consistent with majority voting in both countries.

Pravin Krishna

Johns Hopkins University 1740 Massachusetts Avenue, NW Washington, DC 20036

and NBER

pravin_krishna@jhu.edu
Devashish Mitra

Department of Economics

The Maxwell School of Citizenship and Public Affairs

Syracuse University

Eggers Hall

Syracuse, NY 13244

and NBER

dmitra@maxwell.syr.edu 


\section{Reciprocated Unilateralism in Trade Reforms with Majority Voting}

\section{Introduction}

Reciprocal tariff reductions in the context of trade negotiations have been extensively studied in the theoretical literature on international trade. ${ }^{1}$ Recently, however, the literature has also begun studying the potential interdependence of trade policies across countries even in the absence of trade negotiations, specifically the role of unilateral (i.e., unconditional) liberalization in securing a reciprocal reduction in trade barriers by partners. ${ }^{2}$ Interdependencies of this nature carry important normative implications. The policy of using unconditional liberalization to induce reciprocity by partners stands in contrast to conventional policy wisdom regarding the use (or the threat) of one's trade barriers to remove those of others. Understanding the channels that link trade policies across countries is important from a positive standpoint as well as it may help us understand better particular episodes of reforms undertaken by countries.

In this paper, we explore the link between unilateralism and reciprocity in a context in which the decision to carry out a trade reform is determined by its popular political support. That

\footnotetext{
${ }^{1}$ Thus, for instance, Mayer (1981) showed that in the presence of terms of trade motivations for tariffs, international negotiations could lead to a better outcome than the non-cooperative Nash outcome derived earlier by Johnson (1953). Equally, political economy influences have been considered in models explaining agreed-upon reciprocal trade liberalization in the work of Mayer (1984), Grossman and Helpman (1995), Hillman and Moser (1996) and Bagwell and Staiger (1999), among others. For exhaustive surveys of the theory and evidence on trade and other kinds of policy reforms, see Rodrik (1994, 1995).

${ }^{2}$ For instance, Coates and Ludema (2001) have argued that in the presence of "political risk" of domestic opposition to trade agreements, unilateral tariff reduction - by lowering the political stakes associated with trade liberalization in the foreign country - may increase the likelihood of a successful outcome in a trade negotiation. In a different economic environment, where trade policy is endogenously determined by the interaction between the government and organized interest groups, Krishna and Mitra (2004) have argued that unilateral trade liberalization in one country may induce reciprocity in partner countries by encouraging the formation (or increasing the relative strength) of the relevant interest groups there - that is, reciprocal liberalization may come about even in the absence of any trade negotiations. See Bhagwati (2002) for a general discussion. For some interesting recent explanations of the generally observed anti-trade bias in trade policy see also Limao and Panagariya (2003, 2004).
} 
is, trade policy changes are voted upon by the public and outcomes are determined by the majority (as, for instance, in Mayer (1981) and Fernandez and Rodrik (1991)). ${ }^{3}$ We model a two-good, two-country trading world in which output in each country is produced by individuals with differing relative productivities in the two sectors (as in Mayer (1998)). In the home country, any proposed trade reforms pit (loosely speaking) individuals in losing (import-competing ) sectors against those in the winning (exportable) sectors but to varying extents (as workers vary in their relative productivities). In this setting, we demonstrate how unilateral trade liberalization by a trade partner may increase the voting support for trade liberalization in the home country. Specifically, a reduction in tariffs by a partner country which increases the world price of the exportable of the home country (and thus lowers the relative price of the importable) lowers the relative wage advantage from working in the home country's import-competing sector. Some workers in the import competing sector prior to the reforms may have previously opposed a move to free trade in the home economy but will now support this move. With a large enough movement in the relative price of the importable good, the protected home economy may then gain majority support for free trade. ${ }^{4}$.

\footnotetext{
${ }^{3}$ In contrast to the literature on trade policy that analyzes the political influence exercised by organized lobbies, the majority voting approach emphasizes democratic pressures on government policy-making. As Alesina and Rodrik (1994) argue, "any government is likely to be responsive to the wishes of the majority when key distributional issues are at stake. Even a dictator cannot completely ignore social demands for fear of being overthrown. Thus, even in a dictatorship, distributional issues affecting the majority of the population will influence policy outcomes." Empirical support for the majority voting model has recently been provided by Dutt and Mitra (2002), who use cross-country data to examine the predictions of the model regarding trade policy.

${ }^{4}$ We should note that the type of result demonstrated in the paper is indeed possible in the classic Johnson (1953) analysis of optimal tariffs if the tariff reaction functions there are upward sloping. There too, a unilateral tariff reduction by one country would result in tariff reductions by the partner (again, if the partner's tariff reaction function is upward sloping). However, it should be clear that our analysis differs in significant theoretical (and finally empirically relevant) ways from the Johnsonian analysis. In our framework, a unilateral liberalization by a country would affect even a "small" country's trade policies, whereas in the Johnsonian analysis, a small open economy keeps its tariffs fixed at zero - independently of the tariffs imposed by the large partner country. Furthermore, in Johnson's analysis, upward sloping reaction functions can only be derived if partner export supply elasticities are falling in partner country tariffs. Our results do not depend upon this monotonic elasticity relationship whose empirical validity itself
} 
When trade policies are determined simultaneously in the two countries, we show the possibility of multiple political equilibria - one in which both countries are protectionist and another in which both freely trade with each other. Starting with trade protection in both countries, a unilateral reform in one country is thus shown to bring about a free trade equilibrium (a self-enforcing state) that is consistent with majority voting in both countries.

\section{A Model with Majority Voting}

Consider an economy with two sectors, $M$ (import-competing) and $E$ (exportable). We assume that both goods in this economy are produced under constant returns to scale using labor alone. However, different individuals have different levels of productivities in the production of the two goods. Thus, we denote by $h_{i}^{M}$ the labor productivity of individual $i$ in sector $M$ and by $h_{i}^{E}$ her productivity in sector $E$. Let $p^{*}$ be the world relative price of good $M$. Thus, its domestic price is $p=p^{*}(1+t)$ where $t$ is the ad valorem import tariff, which takes the value $\bar{t}$ prior to the trade reform and zero once the reform takes place.

A person works in the sector that pays her a higher wage determined by her productivity. She decides to work in sector $E$ if $h_{i}^{E}>p h_{i}^{M}$, i.e., if $h_{i}^{E} / h_{i}^{M}>p$. Thus, her comparative advantage in the production of the export good is $h_{i}^{E} / h_{i}^{M}$, which needs to be greater than the relative price $p$ of the import-competing good for her to decide to work in the export sector. Let us rank individuals in decreasing order of their comparative advantage in $E$ production. This comparative advantage denoted by

$$
R(n)=h_{n}^{E} / h_{n}^{M}
$$

is therefore decreasing in $n$.

Let there be a continuum of individuals in the economy and let their total mass or measure be

may be questioned (indeed most textbook treatments consider the opposite case - that of downward sloping reaction functions) 
normalized to unity. In equilibrium, the marginal worker will be indifferent between working in the export and import sectors. Thus, the equilibrium mass of individuals $n^{*}$ working in the export sector is the solution to the equation

$$
R(n)=p
$$

and so the equilibrium mass working in the other sector is $1-n^{*}$.

Let us assume that individuals have identical Cobb-Douglas preferences, so that each individual has an indirect utility function given by

$$
V(p, I)=v(p) I=I / p^{\gamma}
$$

where $\gamma$ is the exponent on the consumption of the importable in the Cobb-Douglas utility function. If incomes of individuals in the $E$ sector prior to the reforms were derived purely from their labor (in other words, if they were not provided any of the tariff revenue), then we can unambiguously show that individuals who were originally in this sector will benefit from these reforms. The utility of such an individual prior to these reforms is less than post-reform utility as can be seen from the following inequality:

$$
\left[p^{*}(1+\bar{t})\right]^{-\gamma} h_{i}^{E}<p^{*-\gamma} h_{i}^{E}
$$

where the left-hand side is the pre-reform utility and the right-hand side is the post-reform utility. $^{5}$ Thus, all individuals who remain in the $E$ sector prior to the reforms support

\footnotetext{
${ }^{5}$ In this context, it is appropriate to bring in the issue of the distribution of tariff revenue across the population. One alternative is to follow Fernandez and Rodrik in assuming that the tariff revenue is distributed solely among workers originally in sector $E$. We can then restrict the factor endowments and/or the distribution of individual comparative advantage to be such that the above factor-income-based ranking (by the original $E$ sector workers) of the pre- and post-reform situations remain completely unchanged (despite redistributing all the tariff revenue to this group of workers). Thus, the other groups of workers (that move from $M$ to $E$ and that remain in $M$ ) will base their decisions solely on factor-income-driven utility calculations. Alternative assumptions that give us factor-income-driven rankings of the two situations for all relevant groups are that (1) government officials consume the tariff revenue and they form a negligible proportion of the population or (2) a small proportion of the population engage in rent-seeking activities and they expend resources to grab all or part of the tariff revenue that they may share with government officials.
} 
reforms.

We compare next the pre- and post-reform utility levels of those individuals who were originally in the $M$ sector and remain there in the post reform equilibrium. As can be seen from inequality (5) below, all of them are worse off since the pre-reform utility of such an individual (appearing on the left-hand-side of (5)) is clearly less than the post-reform level (expressed on the right-hand-side),

$$
\left[p^{*}(1+\bar{t})\right]^{1-\gamma} h_{i}^{M}>p^{* 1-\gamma} h_{i}^{M}
$$

Finally, we look at the individuals who were in sector $M$ prior to the reforms but are in sector $E$ in the post-reform equilibrium. In other words, they end up moving from $M$ to $E$, which is a relatively more lucrative sector for them after the reforms. Note that given the post-reform relative prices, $E$ might be relatively more lucrative but some of these people may be worse off relative to their pre-reform situation in which the domestic relative price was different. Prior to the reform, the utility of such an individual was $\left[p^{*}(1+\bar{t})\right]^{1-\gamma} h_{i}^{M}$ and after the reform, her utility is $p^{*-\gamma} h_{i}^{E}$. It is easy to show that the ranking of the two states is not the same for all individuals who moved at the implementation of reforms. All we know is that for all the people who are in sector $E$ following the reforms, we have

$$
p^{*-\gamma} h_{i}^{E} \geq p^{* 1-\gamma} h_{i}^{M}
$$

that is, post-reform, they are better off in sector E.

However, it is possible to have

$$
\left[p^{*}(1+\bar{t})\right]^{1-\gamma} h_{i}^{M}>p^{*-\gamma} h_{i}^{E} \geq p^{* 1-\gamma} h_{i}^{M}
$$

for some of these individuals. Thus, in order to calculate how many people support the reforms we need to solve the equation

$$
\left[p^{*}(1+\bar{t})\right]^{1-\gamma} h^{M}(n)=p^{*-\gamma} h^{E}(n),
$$


which in turn is

$$
p^{*}(1+\bar{t})^{1-\gamma}=R(n) .
$$

We denote the solution to this equation by $n_{s}$, the number of people supporting the reforms. ${ }^{6}$

Next, we see how this support for reforms responds to the world relative price of imports and to the size of the original tariffs. It is easy to see by differentiating the above equation that

$$
\frac{\partial n_{s}}{\partial p^{*}}=\frac{(1+\bar{t})^{1-\gamma}}{R^{\prime}(n)}<0 \text { and } \frac{\partial n_{s}}{\partial \bar{t}}=\frac{p^{*}(1-\gamma)(1+\bar{t})^{-\gamma}}{R(n)}<0 .
$$

In other words, the support for the reform is decreasing in the world relative price of imports as well as the initial tariff. And so a trade reform takes place when the world price is below a certain threshold. This threshold world price is the one that solves the following equation:

$$
p^{*}(1+\bar{t})^{1-\gamma}=R(0.5)
$$

With the aid of Figure I, we try to illustrate what constitutes the support for reforms in a country. Domestic voters, indexed by $\mathrm{n}$, are represented on the $\mathrm{X}$-axis while prices are represented on the y-axis. $R(n)=h_{n}^{E} / h_{n}^{M}$ is the downward sloping curve indicating the relative productivity of workers in the exportable sector. The pre-reform domestic relative price of the importable initially is given by $p^{*}(1+t)$ and the initial equilibrium is represented by $A^{*}$ with workers to the left of $A^{*}$ allocated to the exportable sector and the rest to the import-competing sector. The post-reform domestic relative price is given by $p^{*}$ and the

\footnotetext{
${ }^{6}$ Let $n_{R}^{*}$ and $n_{T}^{*}$ be the proportion of the population working in the export sector in the reformed and in the tariff-ridden states of the economy respectively. Then, all the $n_{T}^{*}$ people that originally were and remain in sector $E$ support the reforms. In addition, $\left(n_{s}-n_{T}^{*}\right)$ of the $\left(n_{R}^{*}-n_{T}^{*}\right)$ people moving to $E$ after the reforms also support the reforms.
} 
post-reform equilibrium is represented by $C^{*}$. In other words, after the reform workers to the left of $C^{*}$ are allocated to the exportable sector and the rest to the import competing sector. As proved above, workers to the left of $A^{*}$ (i.e., the workers who are always in the export sector, both pre- and post-reform) will always support the reform because for them the reforms just mean a pure terms of trade gain. Workers to the right of $C^{*}$ (i.e., the workers who are always in the import-competing sector, both pre- and post-reform) will always oppose the reform because for them the reforms mean a pure terms of trade loss and nothing else. The workers in between $A^{*}$ and $C^{*}$ (i.e., the workers who were in the import-competing sector prior to the reform but work in export sector after the reform) will be split in their support for the reforms. Everyone to the left of $B^{*}$ supports the reform and everyone to the right of it is against it. Clearly, the supporters of the reform include people who always work in the export sector and some of the people who, after the reforms, move from the import-competing sector to the export sector. These are the movers who have a greater comparative advantage in producing the export good as compared to the other movers, and therefore find their post-reform position in the export sector relatively more attractive as compared to their pre-reform position in the import-competing sector.

Figure II helps us analyze the comparative static exercise where a large partner country reduces its tariff, which in turn moves the world terms of trade in favor of the small home country. The world relative price of the importable goes down as a result from $p^{*}$ to $p^{\prime}$. $A^{*}$, $B^{*}$ and $C^{*}$ change to $A^{\prime}, B^{\prime}$ and $C^{\prime}$ respectively. In other words, the labor allocation to the export sector and therefore output in that sector increase both pre- and post-reform. The support for the reform also increases. Both the world terms of trade and the domestic terms of trade have moved in favor of the home country's export sector, which makes working in this sector relatively more attractive. This also increases the support for the reform. From an initial situation where the support for the reform is below 50 percent (at $B^{*}$ ), the economy, upon liberalization in its partner country, moves to a situation where the support is above 
50 percent (at $\left.B^{\prime}\right)$. Thus reforms in the partner country lead to reforms at home. ${ }^{7}$

\section{II.1 Large Countries}

We next consider the case of two large open economies trading with each other. The home country's exportable and importable are $E$ and $M$ respectively, while it is the reverse for the foreign country. In this case, the world relative price of the importable will be a function of the tariffs of the two countries. Let the domestic and foreign tariffs be $t$ and $t^{*}$ respectively. In that case we have

$$
p^{*}=p^{*}\left(t, t^{*}\right) \text { where } p_{1}^{*}<0, p_{2}^{*}>0
$$

In this case (with $\bar{t}$ again representing the pre-reform home tariff), the support for the reform at home is the solution to the equation

$$
\left[p^{*}\left(\bar{t}, t^{*}\right)(1+\bar{t})\right]^{1-\gamma} h^{M}(n)=p^{*}\left(0, t^{*}\right)^{-\gamma} h^{E}(n),
$$

which in turn can be written as

$$
\Omega\left(\bar{t}, t^{*}\right)=R(n),
$$

where $\Omega\left(\bar{t}, t^{*}\right)=\left[p^{*}\left(\bar{t}, t^{*}\right)\right]^{1-\gamma}\left[p^{*}\left(0, t^{*}\right)\right]^{\gamma}[1+\bar{t}]^{1-\gamma}$. It is easy to see that $\Omega_{2}>0$ as $p_{2}^{*}>0$. If we rule out the paradoxical possibility that the domestic price may fall with an increase in tariff, we also have $\Omega_{1}>0$. Thus we can state that

$$
\frac{\partial n_{s}}{\partial t^{*}}=\frac{\Omega_{2}}{R(n)}<0 \text { and } \frac{\partial n_{s}}{\partial \bar{t}}=\frac{\Omega_{1}}{R(n)}<0
$$

${ }^{7}$ Our theoretical result regarding reciprocal reforms at home clearly depends on changes in the terms of trade that come about due to the initial reforms in the partner country. In an interesting study investigating (somewhat analogously) the impact of terms of trade changes on domestic policy, Hanson and Spilimbergo (2001) find that positive price shocks to sectors in the US intensive in the use of "undocumented labor" result in reductions of border enforcement preventing illegal immigration. 
In this case, again, a trade reform in the partner country raises support for reforms in the home country. We again get the result that there is a negative relationship between initial home tariff and the support for reform.

In Figure III, we draw the home tariff as a function of the foreign tariff. If the foreign tariff is very high, there is insufficient support at home for reform and home is stuck at its initial tariff. For a foreign tariff below a critical level (given by the solution to the equation $\left.\Omega\left(\bar{t}, t^{*}\right)=R(0.5)\right)$, there is majority support for the reform and the tariff drops to zero. Thus, $R_{1}$ is the home country's reaction function. Similarly, we can draw the foreign country's reaction function $R_{2}$ which conveys the same idea. Figure III shows the possibility of multiple equilibria - either both countries liberalize or both countries remain stuck at their respective initial tariffs. With multiple equilibria, we have a coordination problem here in that the two countries might get stuck in the worse political-economy equilibrium - protection in both countries. If people in each of the two countries are pessimistic about how people are going to behave in the other country with regard to trade policy, we will indeed be stuck in such an equilibrium. Nevertheless, a reform forced on any one of these countries (either by a dictatorial leader or a multilateral agency such as the IMF or the World Bank) against the will of the majority can result in a reciprocal reform in the partner country (supported by the majority). The partner country's reciprocal reform implies that the reform

imposed on the home country will now have popular political support, thus resulting in a new self-enforcing state.

\section{II.2 Individual-Specific Uncertainty}

Fernandez and Rodrik (1991) introduce individual-specific uncertainty regarding the benefit from reforms in order to capture resistance to reforms and status-quo bias in the implementation of reforms. For our analysis, we do not need uncertainty of any kind. However, we 
would still like to discuss how a reduction in the world relative price of the import-competing good will affect the outcome in their model. In the Fernandez-Rodrik model, the workers in the export sector always support the tariff reform as they benefit from it. People who move from the import to the export sector after the reform also benefit. However, there is uncertainty about who will be able to move even though the number of people who will move is known. Thus, even if the majority will ultimately gain from reforms, there may be resistance to reforms if less than 50 percent of the workers are originally in the export sector and at the same time the expected (ex ante) net benefit from reforms for all those who are originally in the import sector is negative.

There are two important factors that could lead to a higher support for the reform with a lower $p^{*}$ in a small open economy. A lower $p^{*}$ first means that there are initially more people in the export sector to begin with (all of whom support the reform) and thus there

are fewer people facing the (individual-specific) uncertain effects of the reforms. Second, the real wage differential in favor of the export sector is also going to be higher, a factor that has a positive impact on the expected net benefit of those people originally engaged in the production of the importable.

\section{Conclusions}

Can unilateral trade liberalization by one country lead to reciprocal liberalization by its partner in the absence of negotiations? In this paper, we explore this causal linkage between unilateralism and reciprocity in the context of a model in which the decision to carry out a trade reform is determined by its popular political support. In this framework, trade policy changes are voted upon by the public and outcomes are determined by the majority. We demonstrate that unilateral trade liberalization by a trading partner increases the (voting) support for trade liberalization in the home country. More specifically, if a partner country 
reduces its tariff, the world price of the importable of the home country will go down and the support for a trade reform in the partner country will go up. When trade policies are determined simultaneously in the two countries, we show the possibility of multiple political equilibria - one in which both countries are protectionist and another in which they both trade freely with each other. 


\section{References}

Alesina, A. and Rodrik, D., 1994, "Distributive Politics and Economic Growth," Quarterly Journal of Economics, 109 (2), 465-490.

Bagwell, K., and Staiger, R., 1999, "An Economic Theory of GATT", American Economic Review.

Bhagwati, J., 2002, "The Unilateral Freeing of Trade versus Reciprocity," in Bhagwati ed., Going Alone: The Case for Relaxed Reciprocity in Freeing Trade, MIT Press.

Coates, D., and Ludema, R., 2001, "A Theory of Trade Policy Leadership," Journal of Development Economics, 65(1), pp 1-29.

Dutt, P. and Mitra, D., 2002, "Endogenous Trade Policy Through Majority Voting: An Empirical Investigation," Journal of International Economics, 58, 107-133.

Fernandez, R., and Rodrik, D., 1991, "Resistance to Reform: Status-Quo Bias in the Presence of Individual Specific Uncertainty," American Economic Review.

Grossman, G. and Helpman, E., 1995, "Trade Wars and Trade Talks," Journal of Political Economy, August, 103(4), 675-708.

Hanson, G. and Spilimbergo, A., "Political Economy, Sectoral Shocks, and Border Enforcement," Canadian Journal of Economics, 34(2001): 612-638.

Hillman, A., and Moser, P., 1996, "Trade Liberalization as Politically Optimal Exchange of Market Access," in Canzoneri et al (eds), The New Transatlantic Economy, Cambridge University Press, Cambridge, UK, 295-316.

Johnson, H., 1953, "Optimum Tariffs and Retaliation", Review of Economic Studies, 21, $142-53$.

Krishna, P., and Mitra, D., 2004, "Recioprocated Unilateralism: An Interest Group Approach," Journal of International Economics, Forthcoming.

Limao, N., and Panagariya, A., 2003, "Inequality as a Source of Anti-Trade Bias in Trade Policy," ¡Mimeo, University of Maryland.

Limao, N. and Panagariya, A., 2004, "Anti-Trade Bias in Trade Policy and General Equilibrium," Contributions to Economic Analysis \&f Policy Berkeley Electronic Press Journals, Vol. 3: No. 1. 
Mayer, W., 1981, "Theoretical Considerations on Negotiated Tariff Adjustments," Oxford Economic Papers, 33, 135-43.

Mayer, W., 1984, "Endogenous Tariff Formation," American Economic Review.

Mayer, W., 1998, "Endogenous Corrections of Economic Policies under Majority Voting," FinanzArchiv, 55(1), 41-58.

Rodrik, D., (1994, "Trade and Industrial Policy Reform in Developing Countries," in J. Behrman and T.N. Srinivasan, eds., Handbook of Development Economics, Vol. III, NorthHolland, Amsterdam.

Rodrik, D., 1995, "The Political Economy of Trade Policy," in G. Grossman and K. Rogoff, eds., Handbook of International Economics, Vol. III, North-Holland, Amsterdam. 


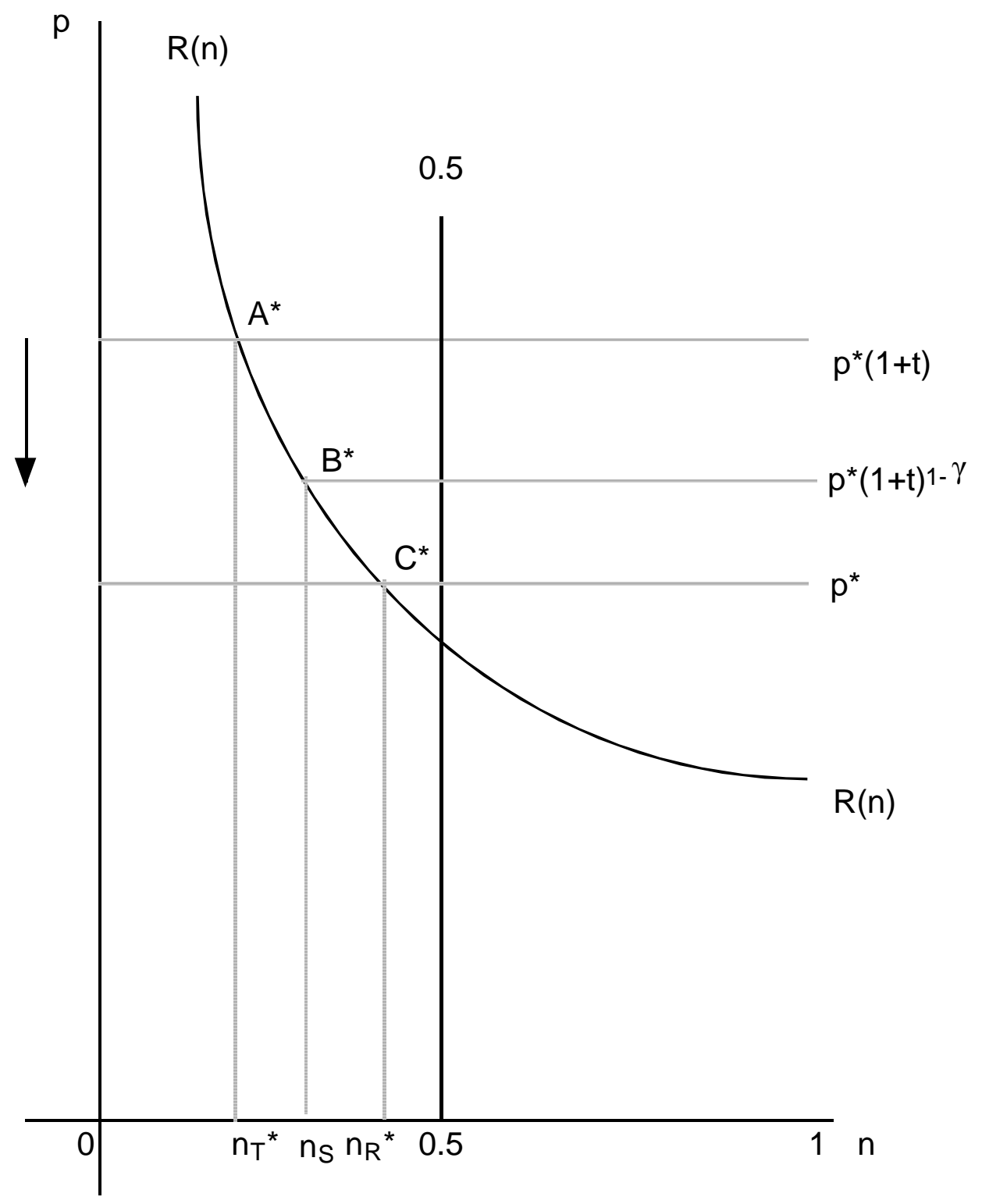

Figure I 


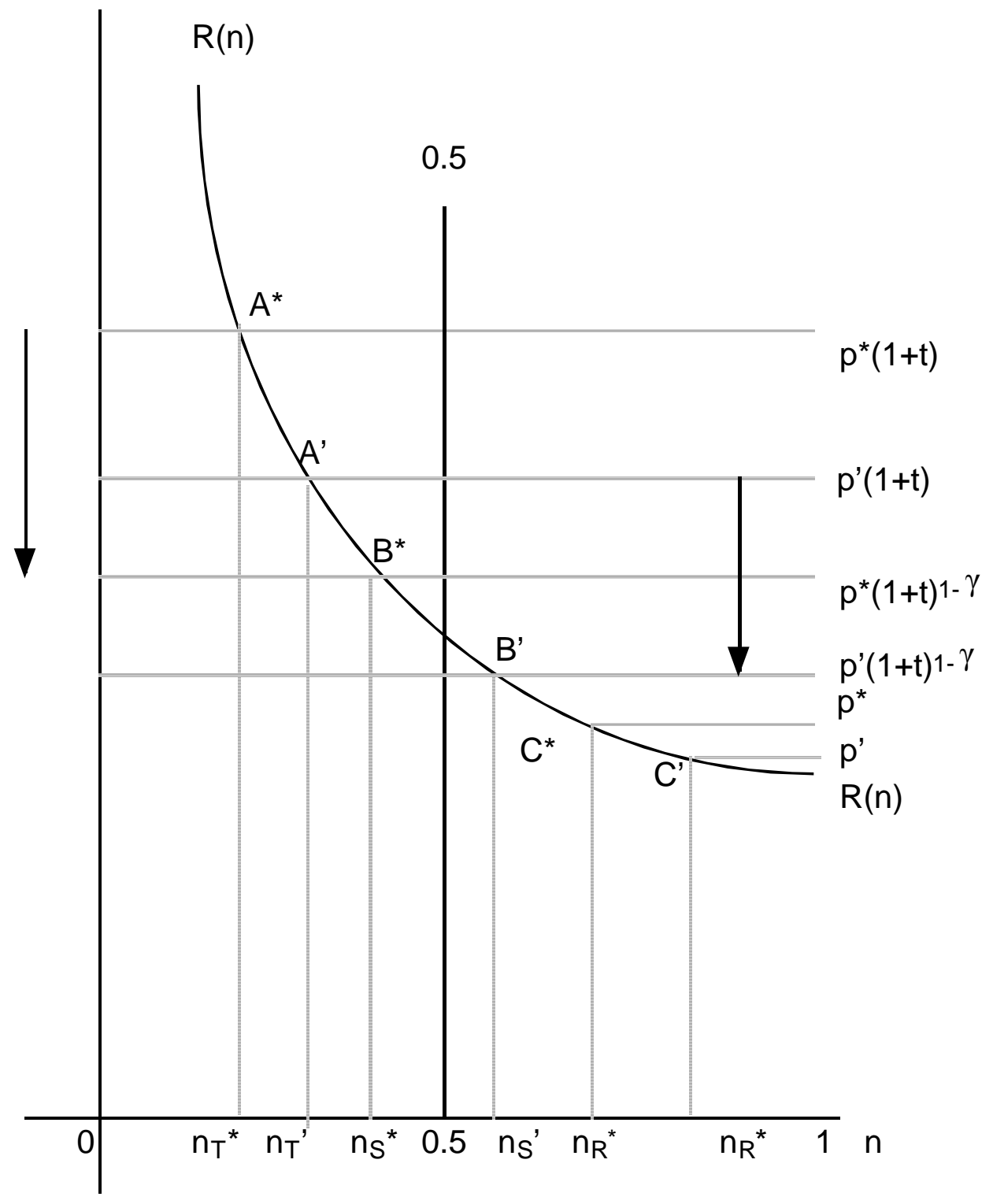

Figure II 


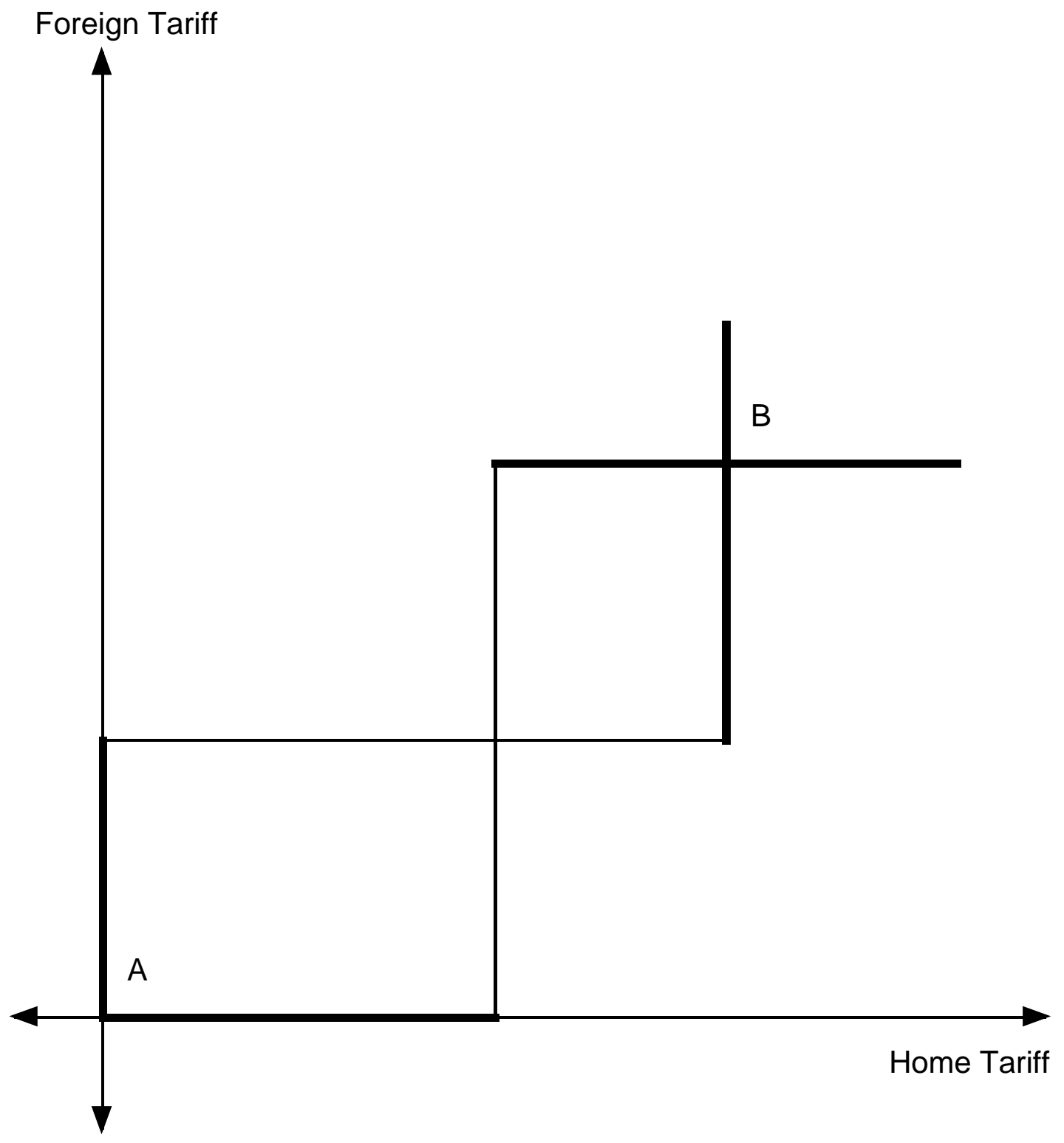

Figure III 